\title{
Nutritional therapy in hospital care of in-patients with Covid-19: evidence, consensus and practice guidelines
}

\section{Terapia nutricional na atenção hospitalar de pacientes hospitalizados com Covid-19: evidências, consensos e guias de práticas}

\section{A B S T R A C T}

\section{Objective}

The objective of this work was to review papers that deal with nutritional therapy of inpatients with Covid-19 from the beginning of the pandemic. The survey covered the period until the month of September 2020.

\section{Methods}

This is a review of the indexed literature (Scopus, Pubmed and Lilacs), including area consensus.

\section{Results}

The review showed that the initial recommendations were based on generic assumptions and, as specific knowledge was being produced, the recommendations became more targeted.

1 Universidade Estadual Paulista, Faculdade de Ciências Farmacêuticas, Programa de Pós-Graduação em Alimentos e Nutrição. Araraquara, SP, Brasil.

2 Pontifícia Universidade Católica de Campinas (Puc-Campinas), Centro de Ciências da Vida, Programa de Pós-Graduação em Ciências da Saúde. Av. John Boyd Dunlop, s/n. Jardim Ipaussurama, 13034-685, Campinas, SP, Brasil. Correspondence to: V.A. LEANDRO-MERHI. Email: <vapaleme@gmail.com>.

3 Pontifícia Universidade Católica de Campinas (Puc-Campinas), Programa de Pós-Graduação em Ciências da Saúde, Mestrado em Ciências da Saúde. Campinas, SP, Brasil.

How to cite this article

Weber TK, Leandro-Merhi VA, Bernasconi I, Oliveira MRM. Nutritional therapy in hospital care of in-patients with Covid-19: evidence, consensus and practice guidelines. Rev Nutr. 2020;33:e200212. https://doi.org/10.1590/1678-9865 $202033 e 200212$ 


\section{Conclusion}

In the health crisis generated by Covid-19, in the context of uncertainties related to nutritional care procedures, knowledge and action strategies were generated, coordinated by researchers and health professionals.

Keywords: Coronavirus infection. Nutritional status. Nutrition therapy.

\section{RE S U M O}

\section{Objetivo}

O objetivo deste trabalho foi revisar as publicações que trataram da terapia nutricional do paciente hospitalizado com Covid-19 desde o início da pandemia até o mês de setembro de 2020.

\section{Método}

Trata-se de uma revisão dos trabalhos indexados nas bases de dados Scopus, Pubmed e Lilacs, incluindo consensos da área.

\section{Resultados}

A revisão mostrou que as recomendações iniciais pautaram-se em pressupostos genéricos e, conforme o conhecimento específico foi sendo produzido, as recomendações passaram a ser mais direcionadas.

\section{Conclusão}

Na crise sanitária gerada pela Covid-19, no contexto de incertezas relacionadas aos procedimentos de atenção nutricional, foram gerados conhecimentos e estratégias de ação, coordenados por pesquisadores e profissionais de saúde.

Palavras-chave: Infecções por coronavirus. Estado nutricional. Terapia nutricional.

\section{INTRODUCTION}

According to information issued by the Pan American Health Organization (PAHO), in September 2020, the mark of 30,000,000 cases of Covid-19 was recorded worldwide, with just over 940,000 deaths [1]. The precautions to contain Covid-19 infection remain in place, and even so, the number of cases and deaths increases every day [1]. Although the pandemic originated in Southeast Asia and first spread to the European continent, currently, the region of the Americas corresponds to more than half of the disease cases recorded in the world, both in terms of prevalence and number of deaths. Almost 1/3 of these cases have occurred in Brazil, according to data published by the Ministry of Health, leaving Brazil in a prominent position in the framework of the pandemic [2,3]. Data released at a press conference of the Brazilian Ministry of Health, held in August 2020, indicated that $50 \%$ of the hospitalization rate for severe acute respiratory syndrome was associated with Covid-19 patients, a rate that corresponded to less than $10 \%$ of patients confirmed cases until the date of the assessment [2]. Of the fatal victims, approximately $72 \%$ were over 60 years old, and heart disease and diabetes were the comorbidities that were most associated with the total number of deaths in hospitalized patients in Brazil [2]. In a cross-sectional study that included 14 countries and 13 North American states, during the first epidemiological wave, it was suggested that the risk of mortality in patients under 65 years of age and without comorbidities is actually very small [4]. International studies suggest that, like in Brazil, the elderly represent the highest percentage of fatal victims [4-6].

The Covid-19 pandemic poses challenges to healthcare teams around the world. Even if the hospitalization rates correspond to less than $10 \%$ of the total cases, in absolute numbers they are still quite significant [3]. The protocols and recommendations for hospital nutritional care have 
undergone adaptations for the care of infected patients, aiming, above all, to contain contamination between patients and professionals. When the WHO declared that the Covid-19 infection was a pandemic and social isolation measures were instituted in Brazil, publications addressing Covid-19 and nutrition were scarce. Nowadays, clinical trials involving nutritional therapy are still scarce. However consensuses built on experts' experiences are relevant for the development of guidelines. Thus, the main objective of this paper is to present our current knowledge on nutritional therapy in Covid-19 in-patients.

\section{METHO D S}

This is a review that sought to gather the knowledge available regarding nutritional therapy of adult inpatients with Covid-19, focusing on the following topics: nutritional screening, gastrointestinal symptoms, nutritional therapy in critically ill patients. The review covered consensus hitherto published: the International Guidelines of the American Society for Enteral and Parenteral Nutrition (ASPEN), European Society for Clinical Nutrition and Metabolism (ESPEN) and Australasian Society for Parenteral and Enteral Nutrition (AUSPEN ); National guidelines of the Brazilian Society of Enteral and Parenteral Nutrition (BRASPEN) and guidelines of the Federal Nutrition Council [7-11]. A search was performed in the Scopus, Pubmed and Lilacs databases, using the search strategy "sars cov2" OR "covid 19" AND "nutrit*" AND "critical care" OR "critical illness" OR "therapy", according to the following section titles. Of 226 manuscripts resulting from the survey, 46 were sieved out according to their titles. Excluding duplicates, 31 articles remained which abstracts were read and 15 were selected, because they met the inclusion criteria addressing nutritional therapy. Another three articles were excluded because they did not meet the language criteria. Thus, a letter to the editor, a short report, four reviews, three proposed protocol in the original article format and three of the consensus already considered were included [7-9,12-19].

\section{NUTRITIONAL SCREENING}

The nutritional status of patients has been identified as a possible prognostic factor, just like previously described in other viral infections such as H1N1 and HIV infections [20-22]. The elderly, the population most susceptible to sarcopenia and malnutrition, were the main victims of premature deaths $[23,24]$. In a cross-sectional study, conducted in the city of Wuhan, China, where the infection apparently originated; out of the 182 elderly patients evaluated, $27.5 \%$ were classified as nutritional risk and $52.7 \%$ as malnourished, through the Mini Nutritional Assessment (MNA) [20]. In addition to the high prevalence of malnutrition, regression analyses pointed to the combination of diabetes (OR 2.12), low calf circumference (OR 2.42) and low albumin (OR 2.98) as independent risk factors for malnutrition [20]. Albumin and pre-albumin nutritional markers, have been correlated with prognosis. Pre-albumin, a nutritional marker more sensitive to nutritional variations, has been shown to be a predictive factor for the progression of Acute Respiratory Distress Syndrome (ARDS), suggesting that low levels may be associated with poor nutritional intake, the effect of which interferes in the patient clinical condition [25]. Recent publications not only call attention to older age and malnutrition, but also to poor nutrition and this group also includes obese patients with comorbidities [20,26]. Obesity (Body Mass Index (BMI) $>40 \mathrm{Kg} / \mathrm{m}^{2}$ ), according to a North American study with 4103 patients infected with Covid-19, was the second independent predicting factor of hospitalization, after old age [27]. 
Evidence shows that the greater the severity of obesity, the greater the incidence of severe respiratory symptoms [28].

Although there are strong indications that the nutritional status is related to a poor prognosis for Covid-19 infection, studies evaluating the impact of nutritional support are still scarce [29]. Actually, there is no randomized clinical trial in the field of nutrition published so far in patients with Covid-19. Cross-sectional studies, experience reports, including publications of nutritional assistance protocols in hospitalized patients may be found. Publications of pragmatic protocols for initiating nutritional support in non-severe ill patients are also found, as proposed by a Brazilian team from a hospital and an Italian team [30,31]. In both protocols, traditional methods for assessing nutritional risk are not indicated. In the Brazilian protocol, nutritional risk eligibility criteria are considered based on comorbidities related to the worst prognosis, indicators and symptoms associated with malnutrition. In turn, in the Italian protocol, a simplified method of nutritional screening is considered; this method takes into account weight and height measurements, BMl below $22 \mathrm{Kg} / \mathrm{m}^{2}$, weight loss and low food intake $[30,31]$. The lack of adequate equipment to perform nutritional assessment, the scarcity of materials, especially personal protective equipment, and hygiene precautions to contain the transmission of infection to health professionals, are the main limiting factors for putting into practice the usual recommendations for assessing nutritional risk. In this sense, the Brazilian Society of Enteral and Parenteral Nutrition (BRASPEN), emphasizes the need to change the routine, aiming at distancing the physical contact of the nutrition team with the patient; on the other hand it does not eliminate the need for nutritional screening in the first 48 hours after admission [10]. The European Society for Clinical Nutrition and Metabolism (ESPEN), in its specific guideline for patients infected with SARS-COv2, mentions the different tools accepted for nutritional assessment in clinical practice, including: Nutritional Risk Screening-2002 (NRS-2002), Malnutrition Universal Screening Tool (MUST), Subjective Global Assessment (SGA), Mini Nutritional Assessment (MNA), NUTRIC-score (for patients in intensive care) and Global Leadership Initiative on Malnutrition (GLIM) [8]. However, these tools have not been mentioned in reports and protocols of hospital care for patients suspected or diagnosed with Covid-19. Corroborating with the recommendations of BRASPEN and the Federal Nutrition Council (CFN), the American Society for Enteral and Parenteral Nutrition (ASPEN) recommends carrying out nutritional screening at a distance, using medical teleconsultation or telephone contact and the use of individual Protection Equipment (PPE) for those professionals involved in infected patients nutritional care $[7,10,11]$.

\section{GASTROINTESTINALSYMPTOMS}

Together with the assessment of nutritional risk goes the investigation of gastrointestinal symptoms. In a review work, in which case reports and retrospective studies since the outbreak were selected, it was found that digestive symptoms may prevail in the absence of respiratory symptoms [32]. In this study, in which 2023 patients were included, anorexia, followed by diarrhea, were the most frequent digestive symptoms in adults, with a prevalence of $39.9-50.2 \%$ and $2.0-49.5 \%$, respectively [32]. In addition to diarrhea being a symptom of the infection, the fact that it may also constitute a side effect of the use of medications, can contribute to the worsening of diarrhea and increase the possibility of fecal transmission, since fecal C-Reative Protein (CRP) analyses of infected patients have shown to be positive for Covid-19 [32].

Vomiting, nausea, gastrointestinal bleeding and abdominal pain symptoms have also been described, but less frequently, and vomiting is most common in the pediatric population and 
abdominal pain is most prevalent in critically ill patients [32]. In a European study carried out in patients with mild to moderate infection, diarrhea and inappetence were a few of the most prevalent symptoms in more than $45 \%$ of patients [33]. Autopsy and histological analysis of Covid-19 victims suggest that gastrointestinal symptoms may be caused by direct viral attack, but may also be a result of tissue and organs injury due to the immune response, enhancing the importance of considering them in the anamnesis and in the subsequent evaluations during hospitalization [32]. Likewise, in non-severe patients, olfactory and gustatory dysfunctions, associated with facial pain and nasal obstruction, respectively, which result in anosmia, hypogeusia and ageusia, should be considered in the nutritional assessment and monitoring of the patient, since they directly impact food intake [33].

Dysphagia does not appear as a gastrointestinal symptom associated to Covid-19 infection; however, among older patients this symptom is more frequent, which contributes to an increase in nutritional risk in this population [34]. In critically ill patients, in intensive care therapy, dysphagia is described as a consequence of the extubation process and may contribute to muscle loss in these patients. Prior to the outbreak of Covid-19 a study carried out in 50 critically ill patients who underwent extubation, showed that 7 days after the procedure, no patient had met $60 \%$ of the energy needs and $40 \%$ of the protein needs [35].

\section{NUTRITIONALTHERAPY IN CRITICALPATIENTS}

In the case of critically ill in-patients, considering that this is the evidence base that we have available for decision-making with regard to Covid-19 critical patients, in general, the clinical evolution with high mortality rates can occur, especially if we consider malnourished patients and those with increased infections, complications, hypermetabolism and longer hospital stay, who can often have low energy and protein intake when fed by nutritional therapy [36-43]. When they are undergoing nutritional therapy, it is observed that these critical patients are unable to reach the goals that were defined for energy and proteins, and there is an influence of the energy and protein deficit on the length of hospital stay and mortality $[40,44,45]$. A study showed that critically ill patients on mechanical ventilation, with energy and protein adequacy were associated with a tendency to an increased mortality in 60 days [46]. In the study in question, increased mortality was associated with energy and protein supply of quantities $\geq 2 / 3$ of the prescribed amounts, only in patients with low nutritional risk, in the first seven days of Intensive Care Unit (ICU) admission [46].

In the case of critical patients in an intensive care unit, fed exclusively with enteral nutrition, in a prospective study, more complications, mechanical complications and a higher risk of PCR/albumin were observed in those patients with critical caloric deficit in enteral therapy [47]. In patients with energy and protein deficit, one can observe more complications, longer hospital stay and more time receiving mechanical ventilation, increased risk of infections and prolonged hospitalization [47-49]. In contrast lower hospital and intensive care unit mortality was reported in patients who had energy consumption due to enteral nutritional therapy $\geq 80 \%$ of prescription [50]. In view of the above, it can be inferred the need of the patient's nutritional status early investigation, both in Covid-19 patients admitted to hospital wards, and in those in worse conditions in the intensive care units.

For the screening and initial nutritional assessment, the Malnutrition Universal Screening Tool (MUST) instruments could be considered for remote use and the NRS according to standardized procedures. These are instruments that are already routinely used in hospital clinical practice [51-55]. 
The NRS and the Nutric-score could be applied early to assess nutritional risk in critical patients in the ICU $[56,57]$. And clinical nutritionists should indicate and prescribe oral nutritional supplementation, for those patients with low energy and protein intake from the oral diet [8].

In the most severe cases, where oral feeding is not possible, enteral nutrition should preferably be administered, or parenteral nutrition when enteral nutrition is contraindicated or unable to attain the goals, giving preference to enteral nutrition due to the lower risk of infectious and non-infectious complications $[7,8]$. In both situations, the appropriate selection of formulas must be adjusted according to the clinical evolution of the case.

American Society for Enteral and Parenteral Nutrition recently set forth a few nutritional therapy recommendations for patients with Covid-19 in intensive care units for the implementation of enteral nutrition, starting with low concentrations of energy and protein, in relation to the targets, and progressing with the solution concentrations according to the patient's evolution; although many of these recommendations are based on earlier American and European guidelines [7,8,57-59].

The determination of the energy and protein goals, previously set by the guidelines on nutritional therapy of the American Society of Parenteral and Enteral Nutrition (ASPEN), were defined as an energy goal of $25-30 \mathrm{Kcal} / \mathrm{kg}$ of body weight per day, and a protein goal of $1.2-2.0 \mathrm{~g} / \mathrm{kg}$ of body weight per day, with other specific recommendations for patients with obesity [57]. Jayawardena et al. [60] performed a systematic review in order to identify evidence regarding supplements prescription and vitamins, minerals, nutraceuticals and probiotics as modulators of respiratory and immune function, showing a favorable effect on the depleted population, as is usually the case with the elderly.

The European Society for Clinical Nutrition and Metabolism (ESPEN), in 2020, provided nutritional recommendations for these Covid-19 patients, considering the nutritional risk that these patients may present due to the extended hospital stay [8]. It is important to emphasize that these recommendations were based on current ESPEN guidelines, expert advice and clinical experience, due to the scarcity of studies related to the nutritional treatment of Covid-19 infected patients.

The estimate of the energy needs proposed by ESPEN of $27 \mathrm{Kcal} / \mathrm{kg}$ of body weight for patients aged $>65$ years with comorbidities; $30 \mathrm{Kcal} / \mathrm{kg}$ body weight for patients with comorbidities and with severe low weight and $30 \mathrm{Kcal} / \mathrm{kg}$ body weight in the elderly were based on previous ESPEN guidelines and allowed to be adjusted according to nutritional status, disease, physical activity and individual tolerance $[8,61,62]$. And the protein needs, of $1 \mathrm{~g}$ of protein $/ \mathrm{kg}$ of body weight/day in the elderly; and $1 \mathrm{~g}$ of protein/ $\mathrm{kg}$ of body weight/day in patients with comorbidities, aiming to avoid loss of body weight and reduction of complications, should also be adjusted according to the criteria mentioned above and were based on the same previous guidelines $[8,61,62]$. And a current proposal for nutritional care in the clinical practice of Covid-19 patients was recently described, suggesting that nutritional herapy be adapted according to the patient's needs, between 25 and $35 \mathrm{Kcal} / \mathrm{kg}$ of body weight/day; and at least 1 $\mathrm{g} /$ protein/kg of body weight/day, for most patients [51].

For critical patients with Covid-19, in an intensive care unit and on mechanical ventilation, the nutritional guidelines so far, regarding the location of the probe, calories, initial volume of the solution, type and composition of the formulas, solution concentration progression, should follow ESPEN guidelines already recommended for critically ill patients in intensive care [59]. Overfeeding is harmful in critically ill patients and leads to increased levels of pCO2, together with delayed respiratory weaning, possibility of pulmonary edema and arrhythmias, symptoms that are also due to Covid-19. Gradual progression of the diet is thus fundamental $[7,8,59]$. 
Another issue to be considered, still from a nutritional point of view, is the significant association between the prevalence of obesity and severe cases of Covid-19, including critical patients, as observed in a preliminary analysis of Covid-19 patients in France $[28,63,64]$. The study's findings suggest that obesity could be a risk factor for the evolution of the condition, especially for those patients in intensive care units anthropometric measures and metabolic parameters are thus important to assess the risk of complications in these patients $[63,64]$.

Chart 1 lists the reviews and protocols proposals found in the survey [9,14-19]. As it turns out, these works offer specific recommendations resulting from clinical practice and inferences from studies and accumulated knowledge with critical patients. Recommendations for obese and non-obese patients are highlighted (Figure 1) the indications for enteral and parenteral nutritional therapy, diet progression and continuous nutritional monitoring, which includes: assessment of nutritional risk, monitoring of the feedback syndrome and assessment of the outcome of applied nutritional therapy and a strict monitoring of patients in prone positioning is essential $[7-9,14,15,18]$. Figure 2 shows the algorithm for nutritional management of hospitalized patients with Covid-19 $[7-11,14,18,31,33]$.

Chart 1. Review studies and protocols proposed for nutritional therapy published until September 2020.

\begin{tabular}{lll}
\hline Study Title & Study type and design & \multicolumn{1}{c}{ Objective } \\
\hline Nutritional & Narrative review & Indicate nutritional \\
management of the & & requirements and \\
critically ill inpatients & & nutritional support \\
with Covid-19. A & in Covid-19 critical \\
narrative review [14]. & patient.
\end{tabular}

Highlights
Patient with non-invasive ventilation:
Oral nutritional supplement (hypercaloric and
hyperproteic): intake $<60 \%$ of EE/2 days.
Enteral nutrition: insufficient intake for more than 5
days.
Patient with invasive mechanical ventilation:
Hypocaloric EN $15-20 \mathrm{Kcal} / \mathrm{kg} /$ day $(10-20 \mathrm{~mL} / \mathrm{h}$ ) with
slow progression up to $75 \% \mathrm{EE}$ on the $3^{\text {rd }}$ day. Control
of potassium, phosphorus and magnesium serum
levels.
Isocaloric EN $25-30 \mathrm{Kcal} / \mathrm{kg} /$ day after the $5^{\text {th }}$ day ( $>80 \%$
EE). Proteins: $1.2-2.0 \mathrm{~g} / \mathrm{kg} / \mathrm{day}$.
Obese: $1.3 \mathrm{~g} / \mathrm{kg}$ of adjusted weight/day.
Post ventilation:
Hypercaloric diet ( $30-35 \mathrm{Kcal} / \mathrm{kg} /$ day) and hyperproteic
diet ( $\geq 2.0 \mathrm{~g} / \mathrm{kg} / \mathrm{day}$ ).
Patients at risk for refeeding syndrome:
Start with $25 \%$ of the EG and slow progression after
72 hours. Phosphate, potassium and magnesium
monitoring.

Relevant nutrition therapy in Covid-19 and the constraints on its delivery by a unique disease process [15].

\section{Narrative review}

Describe practical

and relevant

recommendations on how to optimize nutritional therapy in critically ill patients and patients with Covid-19.
Early EN: $24 \mathrm{~h}$ to $36 \mathrm{~h}$ of admission to the ICU/up to hours of intubation and setting of mechanical ventilation.

Use of standard isosmotic polymeric formula. Formula with fibers after tolerance to EN is established.

Suspension of EN: $\uparrow$ lactate level or hemodynamic instability with the need to increased vasopressor support.

Low dose trophic EN slow progression in 1 week: $70-80 \%$ of caloric requirement $(15-20 \mathrm{Kcal} / \mathrm{kg}$ of current weight/day). Proteins: 1.2 to $2.0 \mathrm{~g} / \mathrm{kg} /$ day. 
Chart 1. Review studies and protocols proposed for nutritional therapy published until September 2020.

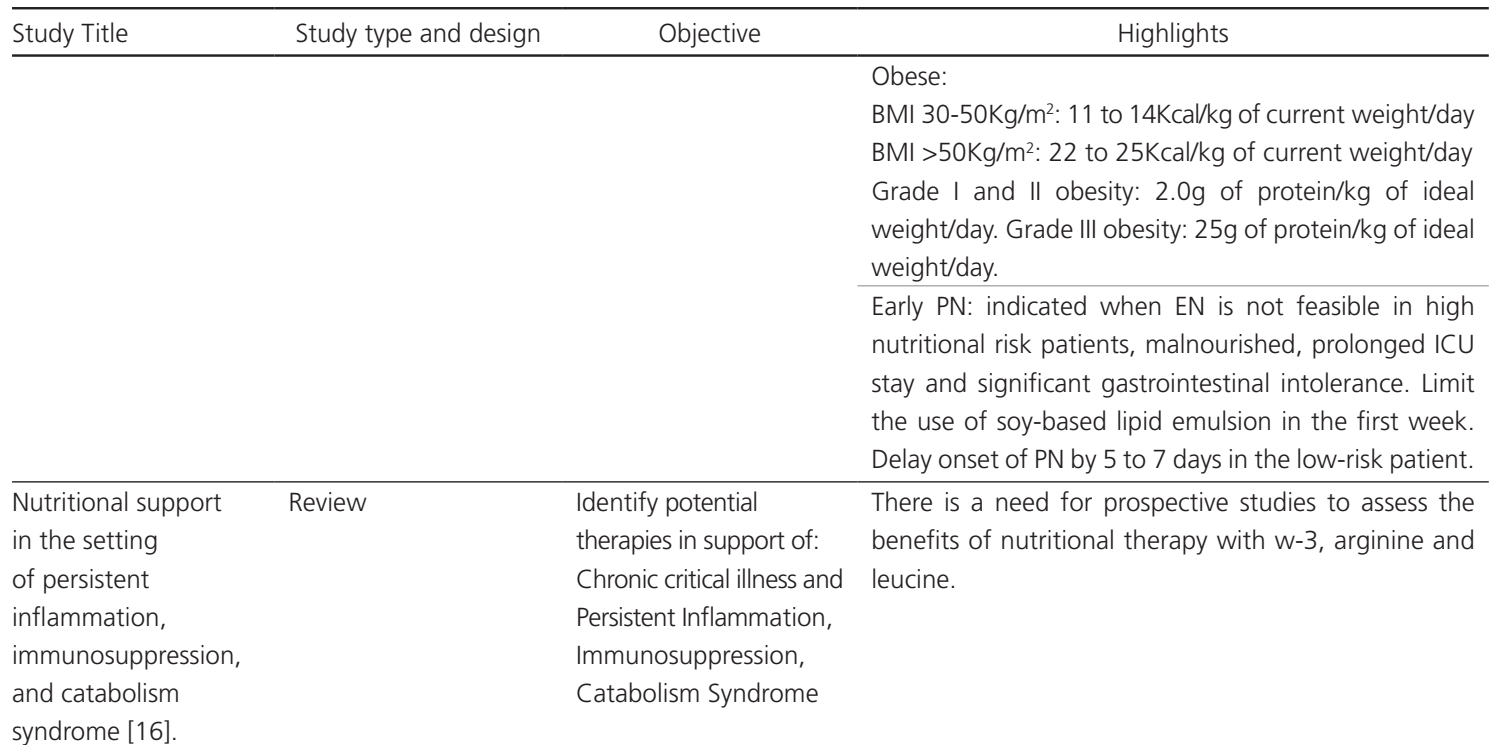

Protocol Nutritional Review Indicate nutritional Critical patients: ESPEN and ASPEN recommendations.

\section{Support in}

Coronavirus 2019

Disease [17] recommendations for

Covid-19, considering the nutritional therapy indicated for patients with viral and bacterial pneumonia and critical patients.

Review nutritional recommendations for nutritional therapy for critically ill patients, aiming to help health professionals working in the ICU, to manage the patient infected by Covid-19.
Patients with mild symptoms of Covid-19: Nutritional support, especially for advanced age or with polymorbidity patients.

Recovered individuals: maintenance of dysphagia tracking and nutritional status.

Probiotics: patients using antibiotic therapy with gastrointestinal symptoms could benefit from using probiotics. However, there is a lack of scientific evidence for such prescription in a Covid-19 infection.

Prevent refeeding syndrome: monitor and administer magnesium, phosphate, vitamins and trace elements in the first 3 days of EN or PN.

Early onset of EN (48h), always in a prone position.

If EN is impossible, contraindicated or insufficient: Individualized NPT. Gradual progression of the diet of $10,15,20$ and $25 \mathrm{Kcal} / \mathrm{kg} /$ day, respectively on the $1^{\text {st }}$, $2^{\text {nd }}, 3^{\text {rd }}$ and $4^{\text {th }}$ day.

Nutritional requirements:

$25 \mathrm{Kcal} / \mathrm{Kg} /$ day and $1.3 \mathrm{~g}$ of protein $/ \mathrm{Kg} /$ day (consider current weight for patients with $\mathrm{BMl}<30 \mathrm{~kg} / \mathrm{m}^{2}$ and ideal weight for obese patients $\mathrm{BMl} \geq 30 \mathrm{~kg} / \mathrm{m}^{2}$ ).

Possibility for oral diet: high energy density and protein. Consider using an oral supplement and request food registration.

Impossibility of oral diet or intubation:

Assessment of nutritional risk and constant nutritional outcome.

EN in the first 24h, via NGT continuous infusion, $1.25 \mathrm{Kcal} / \mathrm{mL}$ at $50 \mathrm{~mL} / \mathrm{h}$ or $1.5 \mathrm{kcal} / \mathrm{mL}$ at $40 \mathrm{~mL} / \mathrm{h}$.

Assess residual gastric volume of all patients, especially in the prone position (every 8h) and indicate the use of prokinetics if GRV $>300 \mathrm{~mL}$. Without altering the intervention, post-pyloric enteral tube or SPL should be considered. 
Chart 1. Review studies and protocols proposed for nutritional therapy published until September 2020.

\begin{tabular}{llll}
\hline Study Title & Study type and design & Objective & Highlights \\
\hline
\end{tabular}

Nutritional assessment to evolve the infusion of the diet or consider a target of $25 \mathrm{Kcal} / \mathrm{kg}$ of weight $/ \mathrm{d}$, first days, if evaluation is not possible. Increase of the target to $25-30 \mathrm{Kcal} / \mathrm{kg} /$ day after 5 days.

\begin{tabular}{|c|c|c|}
\hline $\begin{array}{l}\text { Easy-to-prescribe } \\
\text { nutrition support in } \\
\text { the intensive care in } \\
\text { the era of Covid-19 } \\
\text { [19]. }\end{array}$ & Clinical study & $\begin{array}{l}\text { Develop and evaluate } \\
\text { pragmatic nutritional } \\
\text { protocol in the ICU in } \\
\text { the care of patients } \\
\text { infected with Covid-19 } \\
\text { in University Hospitals } \\
\text { in Geneva (Switzerland). }\end{array}$ \\
\hline
\end{tabular}

Acute phase (1-4 days): $20 \mathrm{Kcal} / \mathrm{kg}$ of estimated weight. Post acute phase (after 4 days): $25 \mathrm{Kcal} / \mathrm{kg} /$ day.

EN: GIT working and not contraindicated.

Gradual progression of the diet:

$1^{\text {st }}$ day $250 \mathrm{~mL} /$ day; $2^{\text {nd }}$ day $500 \mathrm{~mL} /$ day; from the $3^{\text {rd }}$ day, progression by steps, considering addition of $500 \mathrm{~mL} / \mathrm{d}$.

Outcome of PN:

For intubated patients with good tolerance reach 80 to $100 \%$ TER from the $4^{\text {th }}$ day.

For intubated patients without good tolerance until the $4^{\text {th }}$ day: supplementary PN.

For non-intubated patients:

Progression of EN (maximum 1000Kcal/day) assess the possibility of oral nutrition, risk of bronchoaspiration and need for supplementary PN.

NP: GIT not working or EN contraindicated.

$1^{\text {st }}$ day: after electrolyte correction, maximum volume of $625 \mathrm{~mL}$ (central route). $2^{\text {nd }}$ day: $1250 \mathrm{~mL}$

From the $3^{\text {rd }}$ day: progression by steps until $80-100 \%$ of the estimated energy needs are reached.

Outcome of PN:

If good tolerance reaches $80-100 \%$ of needs on the $4^{\text {th }}$ day. If metabolic or electrolytic disorders occur - assess and correct hyperglycemia, assess liver function and triglycerides and check with the nutrition team.

The nutritional protocol assessment questionnaire was sent by email to 122 doctors working in the ICU of University Hospitals in Geneva. 76 professionals answered about the use of the protocol:

44 used it routinely, 26 most of the time and only 6 made little use.

A positive impact on the patients' clinical outcome was reported by 71 of the 75 professionals who answered this question.

Note: BMI: Body Mass Index; EE: Energy Expenditure; EN: Enteral Nutrition; GIT: Gastrointestinal Tract; GRV: Gastric Residual Volume; ICU: Intensive Care Unit; NGT: Nasogastric Tube; PN: Parenteral Nutrition; PNT: Parenteral Nutritional Therapy; SPN: Supplemental Parenteral Nutrition; TER: Total Energy Requirement.

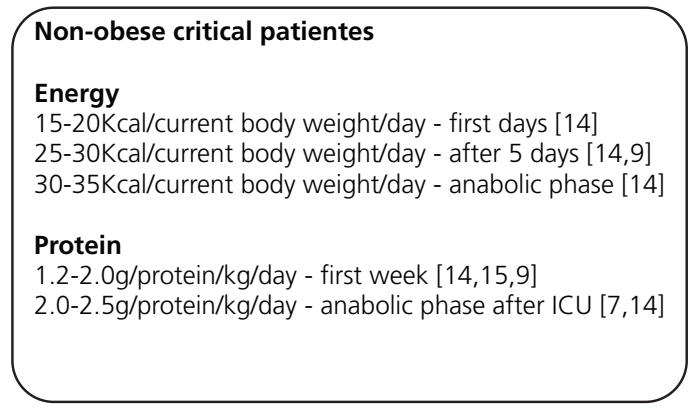

Figure 1. Energy and protein targets estimated. Note: BMI: Body Mass Index.

\section{Obese critical patientes}

\section{Energy}

BMl 30-50 Kg/m²: 11 to $14 \mathrm{Kcal} /$ current body weight/ day [15]

$\mathrm{BMI}>50 \mathrm{Kg} / \mathrm{m}^{2}: 22$ a $25 \mathrm{Kcal} /$ current body weight/ day [15] OR

Value equivalent to non-obese critical patient, with adjusted

body weight $[8,14]$

\section{Protein}

BMI $30-40 \mathrm{Kg} / \mathrm{m}^{2}: 2.0 \mathrm{~g} /$ protein/ideal body weight/day [15] $\mathrm{BMI} 40 \mathrm{Kg} / \mathrm{m}^{2}: 2.5 \mathrm{~g} / \mathrm{protein} / \mathrm{ideal}$ body weight/day [15] OR $1.3 \mathrm{~g} /$ protein ajusted body weight/day $[8,14,18]$ 


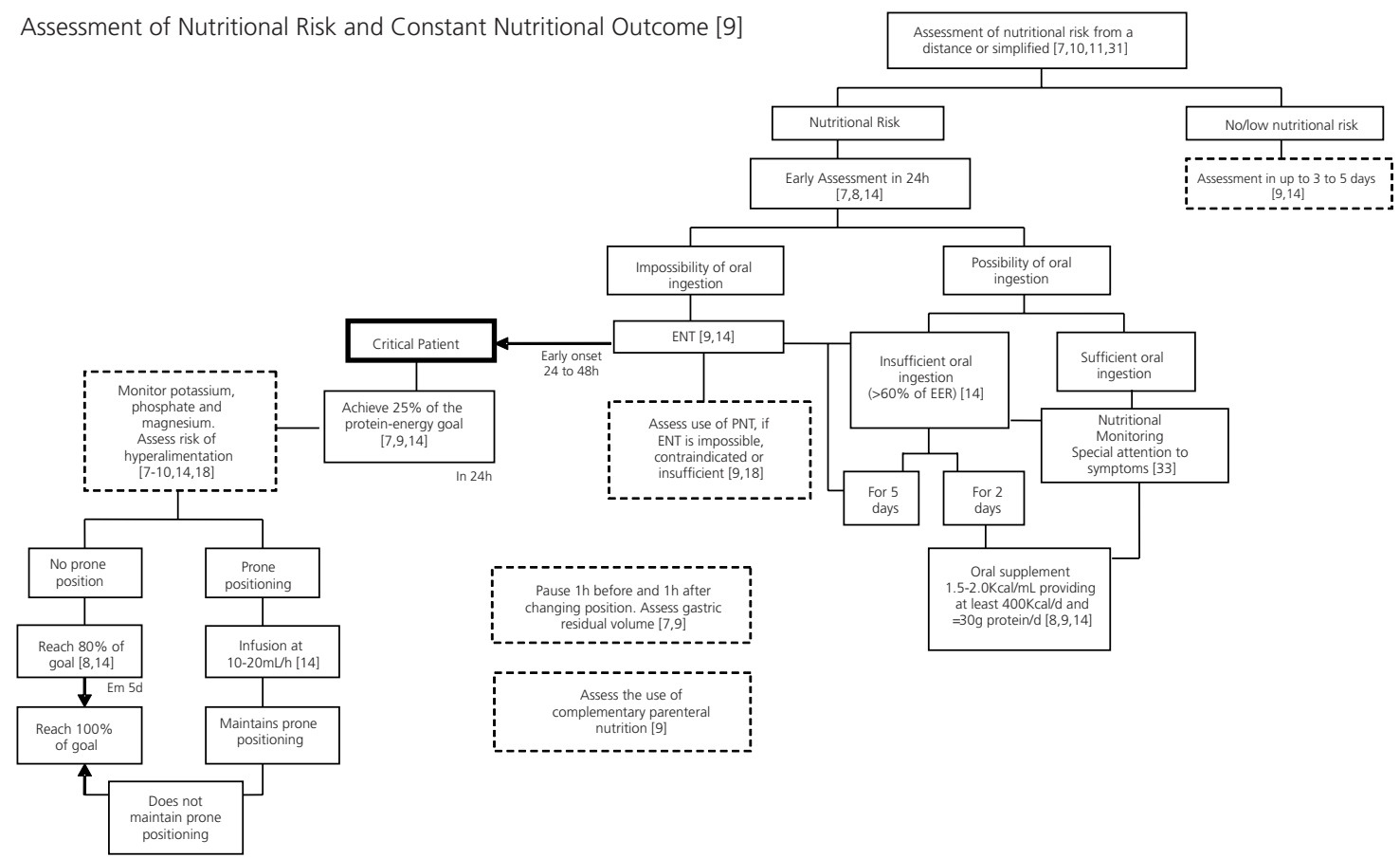

Figure 2. Nutrition algorithm for the management of Covid-19 in patients.

Note: EER: Estimated Energy Requirement; ENT: Enteral Nutritional Therapy; NGT: Nasogastric Tube; PNT: Parenteral Nutritional Therapy.

\section{FIN A L COM M E N T S}

The review of the papers that deal with the nutritional therapy of patients with Covid-19 undergoing hospital treatment showed that, in general, knowledge about the management of patients in nutritional therapy accumulated so far, has supported the decisions and recommendations, yet specific recommendations emerged. It is also interesting to highlight the importance of consensus among experts and knowledge synthesis studies, to generate evidence such as the case of systematic reviews, among others. If, at first, nutritional therapy used less specific evidence, to further incorporate more specific knowledge generated in the clinical practice, it is expected that in a third stage results of controlled clinical studies should emerge to generate even more specific evidence.

\section{A C KNOWLEDGMENTS}

We are grateful for the support of Universidade Estadual Paulista (Botucatu), Brasil and Pontificia Universidade Católica de Campinas.

\section{CONTRIBUTORS}

The authors contributed equally to this work. All authors critically revised the manuscript, agreed to be fully accountable for ensuring the integrity and accuracy of the work, and read and approved the final manuscript. 


\section{REFERE NCES}

1. Organização Pan-Americana da Saúde. Folha informativa COVID-19: escritório da OPAS e da OMS no Brasil. Brasília: Organização; 2020 [citado 19 set. 2020]. Disponível em: https://www.paho.org/pt/covid19

2. Ministério da Saúde (Brasil). Painel Coronavírus, informe virtual publicado em 19 de setembro de 2020. Brasília: Ministério; 2020 [citado 19 set. 2020]. Disponível em: https://covid.saude.gov.br/

3. Cavalcante JR, Cardoso Santos AC, Bremm JM, Lobo AP, Macário EM, Oliveira WK, França GVA. COVID-19 no Brasil: evolução da epidemia até a semana epidemiológica 20 de 2020. Epidemiol Serv Saúde. 2020;29(4):e2020376. https://doi.org/10.5123/\$1679-49742020000400010

4. Joannidis JPA, Axfors C, Contopoulos-loannidis DG. Population-level COVID-19 mortality risk for non-elderly individuals overall and for non-elderly individuals without underlying diseases in pandemic epicenters. Environ Res. 2020;188:109890. https://doi.org/10.1016/j.envres.2020.109890

5. Li J, Xu G, Yu H, Peng X, Luo Y, Cao C. Clinical characteristics and outcomes of 74 patients with severe or critical COVID-19. Am J Med Sci. 2020;360(3):229-35. https://doi.org/10.1016/j.amjms.2020.05.040

6. Hozhabri H, Sparascio FP, Sohrabi H, Mousavifar L, Roy R, Scribano, et al. The global emergency of novel coronavirus (SARS-CoV-2): an update of the current status and forecasting. Int J Environ Res Public Health. 2020;17(16):5648. https://doi.org/10.3390/ijerph17165648

7. Martindale R, Patel JJ, Taylor B, Warren M, McClave SA. Nutrition therapy in the patient with COVID-19 disease requiring ICU care. Aspen. 2020. https://doi.org/10.1002/jpen.1930

8. Barazzoni R, Bischoff SC, Breda J, Wickramasinghe K, Krznaric Z, Nitzan D, et al. Endorsed by the ESPEN council. ESPEN expert statements and practical guidance for nutritional management of individuals with SARS-CoV-2 infection. Clin Nutr 2020;39:1631-8. https://doi.org/10.1016/j.clnu.2020.03.022

9. Chapple LS, Fetterplace K, Asrani V, Burrell A, Cheng AC, Collins P, et al. Nutrition management for critically and acutely unwell hospitalised patients with coronavirus disease 2019 (COVID-19) in Australia and New Zealand. Aust Crit Care. 2020;33(5):399-406. https://doi.org/10.1016/j.aucc.2020.06.002

10. Campos LF, Barreto PA, Ceniccola GD, Gonçalves RC, Matos LBN, Zambelli CMSF, et al. Parecer BRASPEN/ AMIB para o enfrentamento do COVID-19 em pacientes hospitalizados. Braspen J. 2020 [cited 2020 Sep 19];35(1):3-5. https://www.cfn.org.br/wp-content/uploads/2020/03/Parecer-BRASPEN-COVID-19.pdf.pdf

11. Conselho Federal de Nutrição (Brasil). Recomendações do Conselho Federal de Nutrição: boas práticas para a atuação do nutricionista e do técnico em nutrição e dietética durante a pandemia do novo coronavírus (COVID-19). 2020. 3a. ed. Brasília: Conselho Federal de Nutricionistas; 2020.

12. Arkin N, Krishnan K, Chang MG, Bittner EA. Nutrition in critically ill patients with COVID-19: challenges and special considerations. Clin Nutr. 2020;39(7):2327-8.

13. Romano L, Bilotta F, Dauri M, Macheda S, Pujia A, De Santis GL, et al. Short report: medical nutrition therapy for critically ill patients with COVID-19. Eur Rev Med Pharmacol Sci. 2020;24:4035-9.

14. González-Salazar LE, Guevara-Cruz M, Hernández-Gómez G, Zúñiga AES. Nutritional management of the critically ill inpatient with COVID-19: a narrative review. Nutr Hosp. 2020;34(3):622-30. https://doi. org/10.20960/nh.03180

15. Patel JJ, Martindale RG, McClave SA. Relevant nutrition therapy in COVID-19 and the constraints on its delivery by a unique disease process. Nutr Clin Pract. 2020;35(5):792-9.

16. Rosenthal MD, Brakenridge S, Rosenthal CM, Moore FA. Nutritional support in the setting of persistent inflammation, immunosuppression, and catabolism syndrome (PICS). Curr Surg Rep. 2016;4:32. https://doi. org/10.1007/s40137-016-0152-3

17. Stachowska E, Folwarski M, Jamioł-Milc D, Maciejewska D, Skonieczna-Zydecka K. Protocol nutritional support in coronavirus 2019 disease. Medicina. 2020;56:289. https://doi.org/10.3390/medicina56060289

18. Thibault R, Seguin P, Tamion F, Pichard C, Singer P. Nutrition of the COVID-19 patient in the intensive care unit (ICU): a practical guidance. Crit Care. 2020;24:447. https://doi.org/10.1186/s13054-020-03159-z

19. Watteville A, Genton L, Barcelosc GK, Pugin J, Pichard C, Heidegger CP. Easy-to-prescribe nutrition support in the intensive care in the era of COVID-19. Clin Nutr Espen. 2020;(39):74-8. https://doi.org/10.1016/j. clnesp.2020.07.015

20. Li T, Zhang Y, Gong C, Wang J, Liu B, Shi L, et al. Prevalence of malnutrition and analysis of related factors in elderly patients with COVID-19 in Wuhan, China. Eur J Clin Nutr. 2020;22:1-5. https://doi.org/10.1038/ s41430-020-0642-3 
21. Papadimitriou-Olivgeris $M$, Gkikopoulos N, Wüst $M$, Ballif $A$, Simonin $V$, Maulini $M$, et al. Predictors of mortality of influenza virus infections in a swiss hospital during four influenza seasons: role of quick sequential organ failure assessment. Eur J Intern Med. 2020;74:86-91. https://doi.org/10.1016/j.ejim.2019.12.022

22. Johannessen A, Naman E, Ngowi BJ, Sandvik L, Matee MI, Aglen HE, et al. Predictors of mortality in HIVinfected patients starting antiretroviral therapy in a rural hospital in Tanzania. Bmc Infect Dis. 2008;8:52. https://doi.org/10.1186/1471-2334-8-52

23. Rothan HÁ, Byrareddy SN. The epidemiology and pathogenesis of coronavirus disease (COVID-19). Outbreak J Autoimmun. 2020;109:102433. https://doi.org/10.1016/j.jaut.2020.102433

24. Liu K, Chen Y, Lin R, Han K. Clinical features of COVID-19 in elderly patients: a comparison with young and middle-aged patients. J Infect. 2020;80(6):e14-8. https://doi.org/10.1016/j.jinf.2020.03.005

25. Arentz M, Yim E, Klaff L, Lokhandwala S, Riedo FX, Chong M, et al. Characteristics and outcomes of 21 Critically III patients with COVID-19 in Washington state. Jama. 2020;323(16):1612-4. https://doi.org/10. 1001/jama.2020.4326

26. Handu D, Moloney L, Rozga M, Cheng F. Malnutrition care during the COVID-19 pandemic: considerations for registered dietitian nutritionists evidence analysis center. J Acad Nutr Diet. 2020 [forthcoming]. https:// doi.org/10.1016/j.jand.2020.05.012

27. Petrilli C, Jones SA, Yang J, Rajagopalan H, O'Donnel L, Chernyak Y, et al. Factors associated with hospitalization and critical illness among 4,103 patients with COVID-19 disease in New York City. Bmj. 2020;369. https://doi.org/10.1136/bmj.m1966

28. Caussy C, Wallet F, Laville M, Disse E. Obesity is associated with severe forms of COVID-19. Obesity. 2020. https://doi.org/10.1002/oby.22842

29. Laviano A, Koverech A, Zanetti M. Nutrition support in the time of SARS-CoV-2 (COVID-19). Nutrition. 2020;74:110834. https://doi.org/10.1016/j.nut.2020.110834

30. Piovacari SMF, Santos GFCG, Santana GA, Scacchetti T, Castro MG. Fluxo de assistência nutricional para pacientes admitidos com COVID-19 e SCOVID-19 em unidade hospitalar. Braspen J. 2020;35 (1):6-8.

31. Caccialanza R, Laviano A, Lobascio F, Bruno R, Ludovisi S, Corsico AG, et al. Early nutritional supplementation in non-critically ill patients hospitalized for the 2019 novel coronavirus disease (COVID-19): Rationale and feasibility of a shared pragmatic protocol. Nutrition. 2020;74:110835. https://doi.org/10.1016/j. nut.2020.110835

32. Tian Y, Rong L, Nian W, He Y. Review article: gastrointestinal features in COVID-19 and the possibility of faecal transmission. Aliment Pharmacol Ther. 2020;51(9):843-51. http://doi.org/10.1111/apt.15731

33. Lechien JR, Chiesa-Estomba CM, De Siati DR, Horoi M, Le Bom SD, Rodriguez A, et al. Olfactory and gustatory dysfunctions as a clinical presentation of mild-to-moderate forms of the coronavirus disease (COVID-19): a multicenter European study. Eur Arch Otorhinolaryngol. 2020;1-11. https://doi.org/10.1007/s00405-020-0 5965-1

34. Tulunay-Ugur OE, Eibling D. Geriatric dysphagia. Clin Geriatr Med. 2018;34(2):183-9. https://doi.org/10. 1016/j.cger.2018.01.007

35. Peterson SJ, Tsai AA, Scala CM, Sowa DC, Sheean PM, Braunschweig CL. Adequacy of oral intake in critically ill patients 1 week after extubation. J Am Diet Assoc. 2010;110(3):427-33.

36. White JV, Guenter P, Jensen G, Malone A, Schofield M, Academy Malnutrition Work Group, et al. Consensus statement: Academy of Nutrition and Dietetics and American Society for Parenteral and Enteral Nutrition: characteristics recommended for the identification and documentation of adult malnutrition (undernutrition). J Parenter Enteral Nutr. 2012;36:275-83.

37. Correia MI, Waitzberg DL. The impact of malnutrition on morbidity, mortality, length of hospital stay, and costs evaluated through a multivariate model analysis. Clin Nutr. 2003;22:235-9.

38. Lim SL, Ong KC, Chan YH, Loke WC, Ferguson M, Daniels L. Malnutrition and its impact on cost of hospitalization, length of stay, readmission and 3-year mortality. Clin Nutr. 2012;31:345-50.

39. Alvarez-Hernandez J, Planas Vila M, León-Sanz M, Garcia LMA, Celaya PS, García LP, et al. Prevalence and costs of malnutrition in hospitalized patients; the PREDyCES Study. Nutr Hosp. 2012;27:1049-59.

40. José IB, Leandro-Merhi VA, Aquino JLB. Target, prescription and infusion of enteral nutritional therapy of critical patients in intensive care unit. Arq Gastroenterol. 2018;55(3):283-9. https://doi.org/10.1590/\$00042803.201800000-72 
41. Santana MMA, Vieira LL, Dias DAM, Braga CC, Costa RM. Inadequação calórica e proteica e fatores associados em pacientes graves. Rev Nutr. 2016;29(5):645-54.

42. Valizade Hasanloei MA, Vahabzadeh D, Shargh A, Atmani A, Alizadeh Osalou R. A prospective study of energy and protein intakes in critically ill patients. Clin Nutr. 2018;23:162-6.

43. Tsai J-R, Chang W-T, Sheu C-C, Wu Y-J, Sheu Y-H, Liu P-L, et al. Inadequate energy delivery during early critical illness correlates with increased risk of mortality in patients who survive at least seven days: a retrospective study. Clin Nutr. 2011;30(2):209e14. https://doi.org/10.1016/j.clnu.2010.09.003

44. Vallejo KP, Martínez CM, Adames AAM, Fuchs-Tarlovsky V, Nogales GCC, Paz RER, et al. Current clinical nutrition practices in critically ill patients in Latin America: a multinational observational study. Critical Care. 2017;21:227. http://doi.org/10.1186/s13054-017-1805-z

45. Siqueira-Paese MC, Dock-Nascimento DB, Aguilar-Nascimento JE. Critical energy deficit and mortality in critically ill patients. Nutr Hosp. 2016;33(3):522-7.

46. Lee Z-Y, Airini IN, Barakatun-Nisak MY. Relationship of energy and protein adequacy with 60-day mortality in mechanically ventilated critically ill patients: a prospective observational study. Clin Nutr. 2018;37:1264-70.

47. José IB, Leandro-Merhi VA, Aquino JLB, Mendonça JA. The diagnosis and NUTRIC score of critically ill patients in enteral nutrition are risk factors for the survival time in an intensive care unit? Nutr Hosp. 2019;36(5):1027-36. https://doi.org/10.20960/nh.02545

48. Chapple L-AS, Chapman MJ, Lange k, Deane AM, Heyland DK. Nutrition support practices in critically ill head-injured patients: a global perspective. Crit Care. 2016;20:6. https://doi.org/10.1186/s13054-0151177-1

49. Assis MCS, Silveira CRM, Beghetto MG, Mello ED. Decreased calorie and protein intake is a risk factor for infection and prolonged length of stay in surgical patients: a prospective cohort study. Rev. Nutr. 2016:29(3):307-16.

50. Hsu P-H, Lee CH, Kuo L-K, Kung Y-C, Chen W-J , Tzeng M-S. Higher energy and protein intake from enteral nutrition may reduce hospital mortality in mechanically ventilated critically ill elderly patients. Inter J Gerontol. 2018;12(4):285-9. https://doi.org/10.1016/j.ijge.2018.03.001

51. Krznarić Ž, Bender DV, Laviano A, Cuerda C, Landi F, Monteiro R, et al. A simple remote nutritional screening tool and practical guidance for nutritional care in primary practice during the COVID-19 pandemic. Clin Nutr. 2020;10.1016/j.clnu.2020.05.006. doi:10.1016/j.clnu.2020.05.006

52. Elia M. The MUST report: nutritional screening of adults: a multidisciplinary responsibility. Maidenhead: British Association for Parenteral and Enteral Nutrition; 2003.

53. Stratton RJ, Hackston A, Longmore D, Dixon R, Price S, Stroud M, et al. Malnutrition in hospital outpatients and inpatients: prevalence, concurrent validity and ease of use of the "malnutrition universal screening tool" ('MUST') for adults. Br J Nutr. 2004:799-808. https://doi.org/10.1079/BJN20041258

54. Kondrup J, Allison SP, Elia M, Vellas B, Plauth M. ESPEN guidelines for nutrition screening 2002. Clin Nutr. 2003;22(4):415-21.

55. Kondrup J, Rasmussen HH, Hamberg O, Stanga Z, ESPEN working group. nutritional risk screening (NRS 2002): a new method based on a analysis of controlled clinical trials. Clin Nutr. 2003;22(3):321-36.

56. Heyland DK, Dhaliwal R, Jiang X, Day AG. Identifying critically ill patients who benefit the most from nutrition therapy: the development and initial validation of a novel risk assessment tool. Crit Care Med. 2011:15(6):R268.

57. McClave SA, Martindale RG, Vanek VW, Warren MM, Debbie R, Johnson DR, et al. Guidelines for the provision and assessment of nutrition support therapy in the adult critically ill patient: Society of Critical Care Medicine (SCCM) and American Society of Parenteral and Enteral Nutrition (ASPEN). J Parenter Enteral Nutr. 2016;40(2):159-211. https://doi.org/10.1177/0148607115621863

58. Taylor BE, McClave SA, Martindale RG, Warren MM, Johnson DR, Braunschweig CRD, et al. Guidelines for the provision and assessment of nutrition support therapy in the adult critically ill patient: society of critical care medicine (SCCM) and American Society for Parenteral and Enteral Nutrition (ASPEN). Crit Care Med. 2016;44(2):390-438. https://doi: 10.1097/CCM.0000000000001525

59. Singer $P$, Blaser AR, Berger MM, Alhazzani W, Calder PC, Casaer MP, et al. ESPEN guideline on clinical nutrition in the intensive care unit. Clin Nutr. 2019;38(1):48-79. https://doi.org/10.1016/j.clnu.2018.08.037 
60. Jayawardena R, Sooriyaarachchi P, Chourdakis M, Jeewandara C, Ranasinghe P. Enhancing immunity in viral infections, with special emphasis on COVID-119: a review. Diabetes Neta Syndr. 2020;14(4):367-82. https:// doi.org/10.1016/j.dsx.2020.04.015

61. Gomes F, Schuetz P, Bounoure L, Austin P, Ballesteros-Pomar M, Cederholm T, et al. ESPEN guideline on nutritional support for polymorbid internal medicine patients. Clin Nutr. 2018;37:336-53. https://doi. org/10.1016/j.clnu.2017.06.025

62. Volkert D, Beck AM, Cederholm T, Cruz-Jentoft A, Goisser S, Hooper L, et al. ESPEN guideline on clinical nutrition and hydration in geriatrics. Clin Nutr. 2019;38(1):10-47. https://doi.org/10.1016/j.clnu.2018.05.024

63. Caussy C, Pattou F, Wallet F, et al. Prevalence of obesity among adult inpatients with COVID-19 in France [published online ahead of print. Lancet Diabetes Endocrinol. 2020;8(7):562-4. https://doi.org/10.1016/S22 13-8587(20)30160-1

64. Stefan N, Birkenfeld AL, Schulze MB, Ludwig DS. Obesity and impaired metabolic health in patients with COVID-19. Nat Rev Endocrinol. 2020;16:341-2. https://doi.org/10.1038/s41574-020-0364-6

Receveid: August 10, 2020

Final version: October 2, 2020

Approved: October 23, 2020 